\title{
A Study on Port Logistics Supply Chain and Its Flexibility Operation Mechanism in Guangxi Beibu Gulf Based on the Fourth Generation Port Theory
}

\author{
Lan Shi \\ College of Culture Communication in Guangxi University of Finance and Economics, Guangxi \\ Nanning 530003 \\ 148391071@qq.com
}

Keywords: Port, Beibu gulf group, Supply chain, Flexibility operation.

\begin{abstract}
The research of port logistics supply chain has become a hot and key point in the research of port logistics problem. From the existing research results at home and abroad, the port supply chain research has brought to the attention of many people, and has made some achievements, but the research mainly focus on supply chain characteristics and operation mode of the fourth generation of port; it did not do enough on the research of the supply chain flexibility. Because of increasingly fierce market competition and changeable business environment, the port logistics supply chain often face the uncertain risk and fragile, and the diversity of market demand determines the port logistics supply chain must have high flexibility, the construction of flexible supply chain for the port logistics industry is an urgent task. This paper is based on the characteristics of the fourth generation of port logistics in Guangxi Beibu gulf port group as the research object of flexible supply chain operation of supply chain; this paper analyzes the factors of building supply chain flexibility and proposes the construction strategy.
\end{abstract}

\section{Introduction}

With the rapid growth of the global economic integration and international trade, port economy status is increasingly prominent, tits function is expanded. Before 1999, port can be divided into three generation from the perspective of the function of port: the first generation port is located in the transportation hub; its function mainly lies in transportation of shipping goods, temporary storage and transceiver. Compared with the first generation port, the second generation port increase the industry and commerce function, that is value-added (its characteristic is to be a transport of goods loading and unloading and service center). The third generation port is a logistics center(the third generation of port stronger links with the city and user, make the port service beyond the limits of the past, add transportation, trade, information services and goods distribution and other integrated services). Although each port is different in development level, development direction, but basically belongs to a classification system. And then put forward the concept of the fourth generation port in 1999. At present, the fourth generation port development on international is not fully mature, most of the ports in our country is still in the third generation, only a few transit to the fourth generation, in the process from the first generation, second and third generation to the fourth generation, the port logistics will be the most obvious features.

\section{Concept definition of the fourth generation port}

In 1999, the United Nations Commission on Trade and Development (UNCTAD) put forward: the fourth generation port is mainly lies in container, its development strategy is the alliance of port and waterway and port alliance, its production features are integrated logistics, the key to its success is soft factors such as decision-making, management, promotion and training. This marked that the fourth generation port theory was born.

The Fourth generation port (Fourth - generation port, hereinafter referred to as 4GP) is based on modern supply chain management, the seamless connection between each link associated with port, form a set of economic and trade, it connected with manufacturing and logistics, and other functions 
as a supply chain, which is the most advanced modern mode. 4GP affect economic supply and demand in the global scope, it will play an immeasurable role in driving the economic development in the country, region, even in the whole world. At present, the big ports abroad, such as Singapore, Rotterdam, Dubai, Pusan and so on, has developed to the direction of internationalization, intelligence, flexibility, further development of the value-added services of port supply chain, thus come into 4GP era.

Since the United Nations Conference on Trade and Development (1999) put forward the fourth generation port, many scholars regard port as a component of the supply chain, or study the fourth generation port blended in port supply chain system, which provides a new perspective for the development of port logistics. Although the port logistics research is still in the immature stage and the definition of port logistics has not yet reached a consensus, the world's biggest ports still speed up the development of port logistics, domestic ports have also speeded up the planning and construction of port logistics. The practice of the port logistics has developed from traditional logistics, distribution logistics and the stage of comprehensive logistics, it has become a hot problem for government regulators and the theoretical circle to further explore the development direction of port logistics in order to improve its efficiency, reduce logistics cost. At the same time, the development of port practice also presents the cooperation and competition situation, formed the longitudinal alliance, such as the port cargo alliance, port and waterway alliance, as well as the horizontal alliance in the form of the port of Hong Kong alliance. From the nature of competition, competition has surpassed the competition between point and point, and further formed the competition between line and line, or even line surface combination. It is visible that the practice and theory research of the port logistics has blended in port supply chain system, port logistics supply chain has become a new port logistics development direction.

\section{Supply chain flexibility and its operation mechanism}

The concept of supply chain is originated from the concept of Extended Production, modern management education defined supply chain as supply chain is function nets chain structure, which is around the core enterprise, through the control to the business flow, information flow, logistics and cash flow, starting from the procurement of raw materials, made of intermediate products and final products, and finally sales the products to consumers by the sales network, it is aimed to connect manufacturers, distributors, retailers, until the end user together as a whole.

Flexibility of Supply Chains reflects the Flexibility of Supply chain system, namely the ability to change with the market demand, process rapidly and economically the environment in enterprises in the production and business operation activities or the uncertainty caused by environment; it is generally made up of the ability of buffer, adaptation and innovation. In 1987, Slack N put forward the concept of supply chain flexibility for the first time. He thought that supply chain flexibility refers to the ability to make reflect to the customers' demand. Later, a large number of foreign scholars began to take flexible supply chain as an important index for supply chain performance evaluation. Voudouri is the earlier scholar that put forward that to take the flexibility as a indicators of supply chain performance evaluation, Beamon also think flexibility is indispensable important indicator to the index system in researching on the performance evaluation of supply chain. In our country, Professor Ma Shihua also pointed out that supply chain flexibility refers to the expectations of future changes for the buyer; while for the supplier; it is used to estimate the volatility that one can withstand.

In summary, the connotation of supply chain flexibility express mainly from the adaptability of supply chain system, innovative strategic choice of strategic flexibility, flexible system's own ability to change the structure, and the ability to change the operating flexibility in flexible behavior. There exists no obvious progressive relationship between all levels, respectively reflect changes in the environment and influence each other and promote each other.

Briefly speaking, flexible supply chain will take the customer as the center; the enterprises share knowledge, resources, while at the same time to build a supply chain system that can make rapid 
adjustments of the change of internal and external market conditions. A flexible supply chain should have a strong sensitivity to the market, at the same time within the system of elasticity, inductance, high reactivity, and with high enforceability and learning.

The key point of this paper lies on the port logistics supply chain flexible operational mechanism, which is based on flexibility of supply chain management concept, refers to use collaborative management mode, the parallel operation flow, the networked organization structure management thinking to enhance the flexible to cope with change, is a kind of management thought, this paper will research the essential feature of port logistics supply chain and the core content of flexible ability from the perspective of operational research.

\section{Study on the flexibility operation mechanism of supply chain in Guangxi Beibu gulf group}

\section{A summary of development problems in Guangxi Beibu gulf group}

Port group is an important concept used for port planning and management, its development scale and nature are interacting and interdependent, its geographic location adjacent or close to each other, thus to form a set of port region combination, which is called the port group.

Guangxi beibu gulf port group is made up of three coastal ports, and a river port, respectively is: the Jinzhou port and Fanching port, Beihai port and Nanning port. Guangxi beibu gulf port backing the southeast China, and facing southeast Asia, to the east are Guangdong province, Hong Kong and Macao, is the most convenient sea route in southwest China, it is also China's important port of maritime trade with ASEAN countries, is listed as one of the important regional ports. In recent years, under the support of country, Guangxi beibu gulf port group developed rapidly, but compared with our country's trade volume, the market demand and requirements for 4GP, the development of port industry in China is lagging behind. In the face of the fierce global competition environment, Guangxi beibu gulf port has the following problems that must to be solved: how to integrate supply chain flexibility mechanisms into the supply chain system and the problems in port logistics, construction and development of 4GP, and how to build flexible port.

\section{Study on the flexibility operation strategy in Guangxi Beibu gulf group}

Now port logistics supply chain exists in the form of a superposition of multidimensional network organization, which can bring the port group logistics supply chain system some advantages, such as complementary advantages, improve the service integration, and improve co-ordinated and collective learning and so on. Therefore, port group of supply chain system (network) is the organization forms that with dynamic characteristics. Each node in the supply chain system to participate in the activities of port group in supply chain in the form of response. Take each node as an enterprise and to form a network, namely the functional logistics enterprises, the node can be flexible to choose to join or quit a one-dimensional port logistics supply chain system, and the whole system will also change with the dynamic change of the nodes. We can simply express the process of one-dimensional port logistics from Figure 1. Among them, the port 1, port 2, and port $\mathrm{n}$ represents the collection of single functions like loading and unloading, warehousing, distribution and so on.

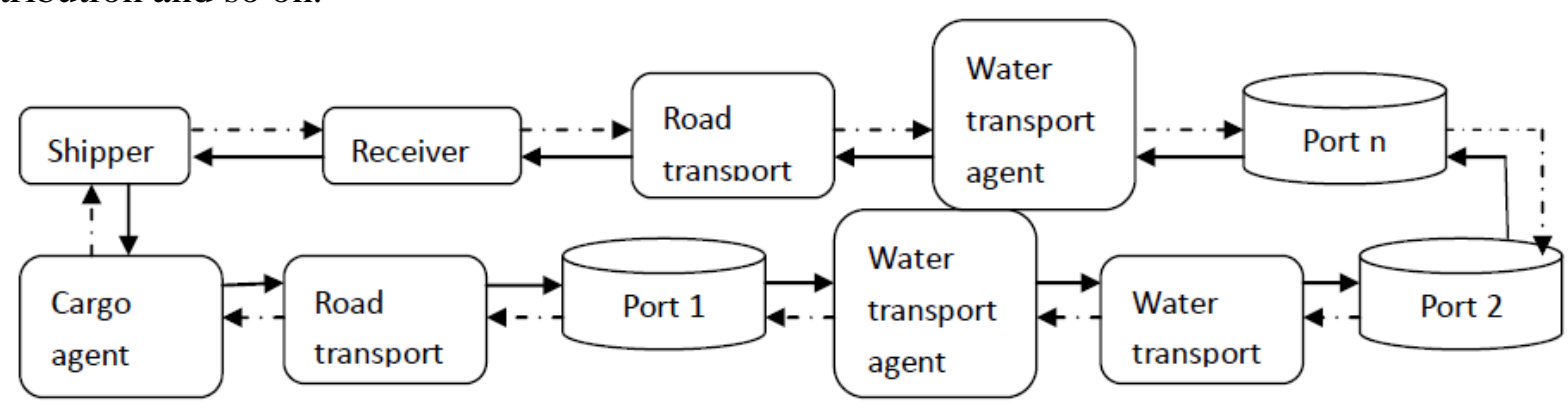

Fig. 1 Diagram of one-dimensional port logistics supply chain system

Remarks: $\longrightarrow$ Real logistic; - - - Information flow 
Port group logistics supply chain system is superposition of more than one one-dimensional supply chain system such as shown in figure 1 . Thus to build its diffusion based on each key nodes in the one-dimensional system (port 1 , port $2 \ldots$ port $n$ ) is the foundation of the whole supply chain flexibility of port group.

(1) Strengthen port alliance, give fully play to the role of logistics area, realize flexible "port". An important member of Guangxi Beibu gulf port group is Qinzhou port, consists of Qinzhou bonded port area. Qinzhou bonded port area is the only bonded area in the west coast in our country, the nearest from ASEAN. in recent China bonded harbor area, located in the forefront of China ASEAN international thoroughfare and southwest China, it is also the core platform and powerful engine of Guangxi Beibu gulf economic zone opening development, the bridgehead of China ASEAN free trade area, an regional international shipping center, logistics center and export processing base opened to international, it is also the only bonded port area columned as vehicle import ports, it can share special preferential policies, such as tax refund or exemption and preferential policies, and preferential policies of Guangxi Beibu bay economic zone opening development. We should give full play to policy advantages of free trade zone and location advantages of Guangxi Beibu gulf port group, realize port linkage, realize the formation of free trade zone and port benign interactive development situation and implementation "port flexibility".

(2) Building a supply chain alliance, realize "port service flexibility". The port ia a collection of loading and unloading, warehousing, shipping, distribution and logistics functions, as shown in figure 1, ports involved in the supply chain system, need to form the effective flexible, and stable relationship with other nodes, moreover, it is necessary to form effective integration between upstream and downstream supply chain partners (port). Guangxi beibu gulf port group should be in an open stance, build a cooperation platform, seeking differentiated service advantages that can meet the demand of the supply chain upstream and downstream nodes, solid position in the supply chain system with strong supply chain alliance. We should pay attention to the optimization of port operations, and make it full of flexibility and adaptability, and realize the port service flexibility.

(3) Extend new development concept, to pursuit port management flexibility. Port development starts late in our country, the development of the traditional concept is formed along the international development path and prone to this, but makes inadequate response to the new environment. The development of supply chain system in Beibu gulf port group should jump out of the old thinking, it requires for innovation and refinement port management, we should improve the construction of port information platform, realize the high information technology of management, seize the development opportunity, and realize the port management flexibility.

\section{Conclusion}

It has become the hot and key point to research of port logistics supply chain, bring port logistics into the supply chain system is an effective way to improve the efficiency of port logistics. From the existing research results at home and abroad, the port supply chain research brought to the attention of the people, and have made some achievements, but because the research time is not long, $t$ but the research mainly focus on supply chain characteristics and operation mode of the fourth generation of port, it did not do enough on the research of the supply chain flexibility, especially the port enterprises. Because of increasingly fierce market competition and changeable business environment, the port logistics supply chain often face the uncertain risk and fragile, and the diversity of market demand determines the port logistics supply chain must have high flexibility, the construction of flexible supply chain for the port logistics industry is an urgent task. Based on the particularity of port logistics supply chain, we cannot copy physical products supply chain flexibility method. So it is necessary to find its flexible operation mechanism, in order to meet the need of the economic and social development.

\section{Acknowledgement}

This subject was supported by Guangxi philosophy and social science planning issues (No.: 13FGL002); 2014 Annual Guangxi College and Universities Research Project (No.: 2014C092). 


\section{References}

[1] Zhang Lian, Feng Gengzhong. The development and Revelation of the typical port logistics at home and abroad [J]. China logistics \& purchasing, 2014(10):16-20.

[2] Zhang Yunbo. Supply chain flexible management for agile manufacturing [J]. Economic reform, 2003(03):55-58.

[3] Zhen Hong. Conception of fourth generation port and its implementation methods [J].Journal of traffic and transportation engineering, 2005(04):90-95.

[4] Zhen Hong. Study on the optimization of port logistics [J]. China port, 1999(08):41-43.

[5] Zhen Hong, Liu Guiyun. The developing mode of the flexible port [M]. Shanghai: Profile of Shanghai Jiao Tong University Press, 2008:11-12. 